\title{
REPRESENTASI PENGETAHUAN DALAM SEMANTIK ONTOLOGI PADA DOMAIN KRIMINALITAS KEPOLISIAN SEKTOR DEPOK TIMUR DAERAH ISTIMEWA YOGYAKARTA
}

\author{
Yusuf Suryo Baskoro ${ }^{(1)}$, Hafsah $\mathbf{S}^{(2)}$, Herlina Jayadianti ${ }^{(3)}$ \\ Jurusan Teknik Informatika, Fakultas Teknik Industri, UPN "Veteran" Yogyakarta, \\ Jalan Babarsari 2, Kec Depok, Kabupaten Sleman, Daerah Istimewa Yogyakarta 55281, \\ Indonesia. \\ Email: yusufsuryobaskoro@gmail.com ${ }^{(1)}$
}

\begin{abstract}
The performance of an agency is very dependent on the data and quality of information obtained, not least in the police agency. The Criminal Investigation Unit (SatResKrim) is one of the most important units in the police force. One form of handling SatResKrim is to manage crime data. Crime data is managed because it contains information to support the investigation process. The information used in the investigation process is included in the crime data, so it is necessary to search for documents of criminal data relevant to the investigation process. Currently, data on SatResKrim unit at East Sector Police Dept. of Yogyakarta Special Region still use Microsoft Excel application, so the process of searching data is still based on text not based on knowledge, consequently if the search keyword is not in accordance with the text contained in the data, then the data is not will appear, if the data does not appear it will slightly hamper the investigation process. From these problems raised the idea to represent police crime data into the form of knowledge as an effort in providing references to the police agencies against the form of development of data processing crime-based semantic ontology. Knowledge of crime data is limited to criminal data by category of theft. Knowledge related to theft criminal data is then stored or represented in an ontology-based semantic model. In representing knowledge using language Ontology Web Language (OWL) and SPARQL as its query. Software used to build systems in this study include protégé 3.5, NetBeans and Jena API as its library. The programming language used is Java Server Page (JSP). Based on the results of research that has been done, by representing crime data into the form of semantic ontology-based knowledge and tested into the form of search-based applications, can generate semantic-based search or search that is able to understand the meaning. It is also supported by test results using recall and precision methods, each of which results in a value of more than $90 \%$.
\end{abstract}

Keywords: Knowledge Representation, Ontology, Semantic Web Abstrak

Kinerja suatu instansi sangat bergantung pada data dan mutu informasi yang diperoleh, tak terkecuali pada instansi kepolisian. Satuan Reserse Kriminal (SatResKrim) merupakan salah satu unit terpenting dalam kepolisian. Salah satu bentuk penanganan SatResKrim adalah dengan mengelola data kriminalitas. Data kriminalitas dikelola karena mengandung informasi guna menunjang proses investigasi. Informasi yang digunakan dalam proses investigasi diantaranya terdapat pada data kriminalitas, sehingga diperlukan adanya pencarian terhadap dokumen data kriminalitas yang relevan dengan proses investigasi. Saat ini data yang berada pada unit SatResKrim pada Kepolisian Sektor Depok Timur Daerah Istimewa Yogyakarta masih menggunakan aplikasi Microsoft Excel, sehingga proses pencarian data masih berdasarkan teks bukan berdasarkan pengetahuan, akibatnya apabila kata kunci pencarian tidak sesuai dengan teks yang terdapat pada data, maka data tidak akan muncul, jika data tidak muncul maka akan sedikit menghambat proses investigasi. Dari permasalahan tersebut memunculkan gagasan untuk merepresentasikan data kriminalitas kepolisian kedalam bentuk pengetahuan sebagai upaya dalam memberikan referensi kepada instansi kepolisian terhadap bentuk pengembangan pengolahan data kriminalitas berbasis semantik ontologi. Pengetahuan-pengetahuan mengenai data kriminalitas dibatasi pada data kriminalitas dengan kategori pencurian. Pengetahuanpengetahuan terkait data kriminalitas pencurian kemudian disimpan atau di representasikan dalam model semantik berbasis ontologi. Dalam merepresentasikan pengetahuan menggunakan bahasa Ontology Web Language (OWL) serta SPARQL sebagai query-nya. Software yang digunakan untuk membangun sistem dalam penelitian ini meliputi protégé 3.5 ,NetBeans serta| 
Jena API sebagai library-nya. Bahasa pemrograman yang digunakan adalah Java Server Page| (JSP). Berdasarkan hasil penelitian yang telah dilakukan, dengan merepresentasikan data kriminalitas kedalam bentuk pengetahuan berbasis semantik ontologi dan di ujikan ke dalam bentuk aplikasi berbasis pencarian, dapat menghasilkan pencarian berbasis semantik atau pencarian yang mampu memahami makna. Hal tersebut juga didukung oleh hasil uji dengan menggunakan metode recall dan precision yang masing-masing hasilnya menunjukkan nilai lebih dari $90 \%$.

Kata Kunci : Representasi Pengetahuan, Ontologi, Semantic Web

\section{PENDAHULUAN}

\subsection{Latar Belakang}

Pada awal perkembangannya, web pertama dikenal dengan sebutan web 1.0. Teknologi web generasi pertama ini bersifat read-only, yang berarti pengguna hanya dapat membaca sebuah informasi dari sebuah web sehingga sering disebut juga dengan sebutan brochureware. Perkembangan pada generasi kedua dinamakan web 2.0. Garis besar web 2.0 adalah berbicara mengenai hubungan komunikasi many-to-many sehingga memiliki sifat share, collaborate dan exploit. Pada era web 2.0 pengguna tidak hanya dapat membaca, tetapi pengguna juga dapat menulis konten mereka sendiri, serta pengguna dapat berbagi dengan pengguna lain, seperti halnya dapat berbagi foto, maupun sebuah video. Maka, tak jarang perkembangan web 2.0 disebut juga sebagai "the social network" (Murugesan, 2007). Tak berhenti pada web 2.0, website masih terus mengalami perkembangan. Generasi ketiga yang lahir dinamakan dengan web 3.0. Web 3.0 dikenal juga dengan semantic web. Konsep dasar pada web 3.0 (semantic web) yang belum dimiliki oleh web 1.0 dan web 2.0 adalah cara mendefinisikan struktur data dan cara menghubungkan data sehingga meningkatkan nilai efisiensi dalam hal pencarian, otomatisasi, dan integrasi di berbagai aplikasi. Semantic web memungkinkan berkembangnya sebuah teknologi dari teknologi berbasis data menjadi berbasis knowledge atau pengetahuan, sehingga memungkinkan komputer mengerti akan suatu makna dari sebuah informasi (Jayadianti,H. 2011). Sebagai contoh, terdapat sebuah kalimat "saya mencuri blackberry". Kalimat tersebut mengandung beberapa makna diantaranya adalah apakah kata "blackberry" berarti buah atau kata "blackberry" berarti sebuah ponsel pintar. Dari contoh kasus tersebut dapat disimpulkan bahwa pada suatu kata atau data bisa bermakna tentang banyak hal sehingga membutuhkan sebuah pengetahuan untuk dapat membedakannya. Jika komunikasi terjadi antar sesama manusia tentu makna pada suatu informasi akan dapat langsung di artikan, namun bagaimana jika kita berkomunikasi dengan sebuah mesin, apakah sebuah mesin dapat begitu saja mengerti apa yang sedang dimaksud oleh manusia, tentu tidak semudah itu, perlu adanya jembatan pengetahuan antara manusia dengan mesin.

Dalam merepresentasikan data atau informasi menjadi sebuah pengetahuan yang dapat dimengerti oleh mesin salah satunya adalah dengan menggunakan metode ontologi. Menurut Tim Berners Lee, ontologi digunakan untuk merepresentasikan informasi menjadi sebuah bentukbentuk basis pengetahuan yang dapat dipahami oleh mesin sehingga sangat memungkinkan dalam meningkatkan pencarian, otomatisasi dan integrasi di berbagai aplikasi (Berners-Lee dkk, 2001). Ontologi sendiri berarti sebuah konsep yang menghubungkan simbol-simbol dengan berbagai bentuk yang di rancang oleh manusia dan dapat diproses oleh mesin, sehingga secara singkat ontologi dapat dikatakan sebagai jembatan antara manusia dengan mesin. (Davies dkk, 2006).

Kinerja suatu instansi sangat bergantung pada data dan mutu informasi yang diperoleh, begitu pula pada instansi kepolisian. Tak hanya kualitas data dan informasi, pengolahan atau pengelolaan data dan informasi juga dibutuhkan guna menunjang hasil kerja yang lebih baik. Beberapa ahli mendefinisikan sebuah informasi, salah satunya menjelaskan bahwa informasi didefinisikan sebagai data yang telah diproses sedemikian rupa sehingga meningkatkan pengetahuan seseorang yang menggunakan data tersebut (Abdul, 2003). Sedangkan menurut ahli lain menjelaskan bahwa informasi didefinisikan sebagai hasil dari pengolahan data dalam bentuk yang lebih berguna bagi penerimanya yang meggambarkan kejadian nyata sehingga dapat digunakan sebagai penunjang dalam pengambilan keputusan (Jogiyanto, 1990). Dari 
penjelasan beberapa ahli terkait definisi informasi, yang perlu digaris bawahi adalah bagaimana memproses atau mengolah data sedemikian rupa dalam bentuk yang lebih berguna guna menghasilkan informasi yang dapat meningkatkan pengetahuan seseorang maupun dapat digunakan dalam proses pengambilan keputusan.

Satuan Reserse Kriminal (SatResKrim) merupakan salah satu unit terpenting dalam kepolisian (Gantini \& Mendrofa, 2012). Sebagai salah satu "ujung tombak" dalam penanganan kasus kriminalitas, peran SatResKrim sangatlah dibutuhkan. Salah satu bentuk penanganan SatResKrim adalah dengan mengelola data kriminalitas. Data kriminalitas dikelola karena mengandung informasi guna menunjang proses investigasi. Informasi yang digunakan dalam proses investigasi diantaranya terdapat pada data kriminalitas, sehingga diperlukan adanya pencarian terhadap dokumen data kriminalitas yang relevan dengan proses investigasi. Saat ini data yang berada pada unit SatResKrim pada Kepolisian Sektor Depok Timur Daerah Istimewa Yogyakarta masih menggunakan aplikasi Microsoft Excel, sehingga proses pencarian data masih berdasarkan teks bukan berdasarkan pengetahuan, akibatnya apabila kata kunci pencarian tidak sesuai dengan teks yang terdapat pada data, maka data tidak akan muncul, jika data tidak muncul maka akan sedikit menghambat proses investigasi.

Dengan merepresentasikan data kriminalitas menjadi sebuah pengetahuan berbasis semantik ontologi, diharapkan mampu meningkatkan nilai efisiensi dalam melakukan proses pencarian data kriminalitas kepolisian, mengingat pentingnya proses pengolahan data kriminalitas sebagai langkah dalam menghasilkan informasi yang dapat digunakan dalam proses investigasi maupun dalam proses pengambilan keputusan pada kepolisian.

\subsection{Tujuan}

Tujuan penelitian ini adalah merepresentasikan data kriminalitas kepolisian menjadi sebuah pengetahuan berbasis semantik ontologi demi meningkatkan efektifitas pencarian data kriminalitas pada Kepolisian Sektor Depok Timur Daerah Istimewa Yogyakarta.

\subsection{Batasan Masalah}

Batasan permasalahan yang menjadi pembatas dalam penelitian ini antara lain adalah sebagai berikut:

1. Fokus penelitian adalah bagaimana cara merepresentasikan data kriminalias ke dalam bentuk model semantik ontologi dengan menggunakan aplikasi protégé 3.5.

2. Hasil uji representasi pengetahuan akan di tampilkan berbentuk aplikasi berbasis pencarian yang di bangun dengan aplikasi netbeans 8.0.2.

3. Data yang digunakan sebagai bahan penelitian adalah beberapa data kriminalitas atau data tindak pidana yang terdapat pada Polsek Depok Timur Daerah Istimewa Yogyakarta.

\section{TINJAUAN PUSTAKA}

\subsection{Semantic Web}

Semantic web pada dasarnya merupakan proses untuk mendefinisikan data menjadi sebuah pengetahuan dengan menggunakan cara-cara atau metode yang bisa dipahami oleh mesin. Kemampuan mesin untuk mendeskripsikan keterikatan antar data serta representasi graph dari data tersebut merupakan tujuan diciptakannya semantic web yang kemudian dapat digunakan oleh mesin bukan hanya sekedar untuk menampilkan sebuah informasi, tetapi juga untuk proses otomatisasi dan integrasi sehingga dapat digunakan kembali dalam aplikasi yang berbeda. Sebagai pendiri perusahaan W3C (World Wide Web Consortium) ,Tim Berners Lee bersama timnya mengatakan bahwa inti dari semantic web adalah mengaplikasikan ontologi untuk merepresentasikan informasi menjadi sebuah bentuk-bentuk basis pengetahuan yang dapat dipahami oleh mesin (Berners-Lee dkk, 2001). 


\section{2. $\quad$ Arsitektur Semantic Web}

Dalam mengaplikasikan ontologi sebagai upaya membangun semantic web, W3C menetapkan beberapa bahasa dasar (basic language) komponen untuk keperluan dalam membangun sebuah ontologi sehinga representasi ontologi dapat dipahami mesin, diantaranya adalah XML,RDF OWL, dan SPARQL (Query Language RDF). Bahasa-bahasa tersebut digambarkan dalam sebuah arsitektur. Arsitektur tersebut terdiri dari beberapa layer seperti yang ditunjukkan pada gambar 1. (Koivunen \& Miller, 2001)

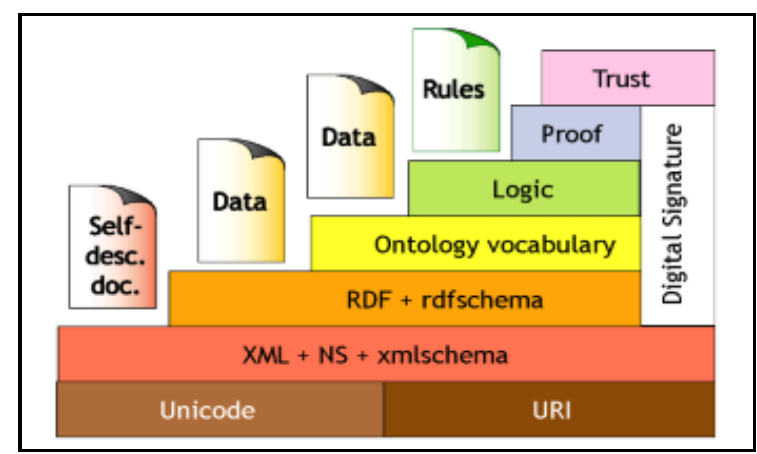

Gambar 1. Arsitektur Semantic Web

\subsection{Ontologi}

Ontologi merupakan teori tentang makna dari suatu objek, properti satu objek, serta relasi objek tersebut yang mungkin terjadi pada suatu domain pengetahuan. Ontologi mengkonsepkan segala sesuatu secara sistematik serta menjelaskannya.

\subsection{Komponen Ontologi}

Ontologi terdiri dari beberapa komponen diantaranya adalah :

1. Individual (Instances)

Individual (Instances) merupakan komponen dasar dari sebuah ontologi. Instances dari sebuah ontologi bisa berupa objek nyata atau juga bisa berupa objek abstrak.

2. Classes

Suatu class menjelaskan konsep-konsep yang ada dalam suatu domain. Biasanya sebuah class merupakan sekumpulan dari objek-objek. Sebuah class juga bisa memiliki subclass yang mana subclass ini akan mempresentasikan konsep yang lebih spesifik daripada superclassnya.

3. Atributes

Objek-objek yang berada dalam ontologi bisa dideskripsikan dengan memberikan tambahan atribut kedalam objek tersebut. Setiap atribut memiliki paling tidak sebuah nama dan nilai, dan digunakan untuk menyimpan informasi yang lebih spesifik tentang objek yang diberi atribut tersebut.

4. Relasi

Suatu relasi menjadi penting dalam sebuah ontologi, karena dalam suatu ontologi relasi antara objek-objek yang ada harus dideskripsikan. Keunggulan dari ontologi berasal dari kemampuannya mendeskripsikan relasi lain. Kumpulan dari relasi akan mendeskripsikan semantik atau arti dari sebuah entitas.

\subsection{Protégé}

Protégé merupakan salah satu perangkat lunak yang digunakan sebagai alat bantu dalam merancang dan membangun sebuah sistem yang didasarkan pada pengetahuan berbasis ontologi. Tujuan penggunaan aplikasi protégé adalah untuk merancang dan membangun ontologi, memodelkan tampilan pengetahuan akuisisi, dan memasukkan domain pengetahuan.

\subsection{SPARQL}

SPARQL merupakan singkatan dari SPARQL Protocol and RDF Query Language. Seperti namanya, SPARQL merupakan bahasa query RDF yaitu bahasa query yang digunakan dalam 
pegembangan web semantik, karena SPARQL dapat mengambil dan memanipulasi data yang tersimpan dalam format RDF. SPARQL dibuat berdasarkan standar RDF Data Acces Working Group (DAWG) dan diakui dan direkomondasikan oleh W3C sebagai salah satu teknologi kunci dari web semantik (Herman, 2008).

Klausa yang digunakan dalam query SPARQL :

1. Prefix

Prefix merupakan mekanisme penentuan awalan untuk menyingkat URI. Misalnya prefix ks:http://www.owl-ontologies.com/OntologyKasus.owl\# berarti URI tersebut disingkat dengan awaln ks.

2. Select

Dalam statement select didefinisikan sebuah daftar variabel-variabel yang akan dikembalikan sebagai hasil dari eksekusi query. Setiap variabel didahului dengan tanda tanya (?) dan bisa diberi nama dengan menggunakan karakter alfanumerik yang direkomendasikan dengan garis bawah (_).

3. From

Pada statement from ini dispesifikasikan jalur atau URL dari dokumen RDF yang akan diquery.

4. Where

Dalam statement where didefinisikan sederetan triple pattern yang harus dimiliki oleh setiap hasil query yang valid. Seluruh pola yang merepresentasikan suatu kalimat RDF harus memiliki bentuk sesuai dengan RDF triple yang terdiri dari subject, predicat dan object.

5. Filter

Pernyataan filter digunakan untuk melakukan pencocokan nilai tertentu dari suatu variabel yang di-query.

6. Optional

Pernyataan optional digunakan untuk menyatakan bahwa apabila salah satu komponen tidak memiliki data akan tetap dikembalikan sebagai hasil query .

7. Union

Pernyataan union digunakan untuk menyimpan data dari solusi query dua buah pola RDF yang berbeda ke dalam sebuah variabel yang sama.

8. Distinct

Hasil query dapat dimodifikasi dengan menambahkan pernyataan distinct yang akan memastikan bahwa setiap kombinasi dari pengikatan variabel pada sederetan hasil query adalah unik.

9. Order by

Pernyataan Order by digunakan untuk mengurutkan hasil query berdasarkan suatu nilai variabel.

\section{METODE DAN PERANCANGAN SISTEM}

\subsection{Metodologi Pengembangan Sistem}

Metodologi pengembangan sistem yang digunakan dalam penelitian ini yaitu menggunakan metodologi Guidelines for Rappid Application Engineering atau disingkat dengan Grapple. Metode grapple digunakan demi menghasilkan sistem berorientasi objek dalam waktu yang singkat tanpa mengurangi kualitas sistem yang dibangun(Pelka, 2017). Terdapat lima bagian pada metode grapple diantaranya adalah sebagai berikut :

1. Requirement Gathering

Tahapan pertama yang harus dilakukan seorang pengembang perangkat lunak adalah dengan mencari informasi lengkap dari pengguna tentang sistem yang akan dirancang dan dibangun.

2. Analysis

Tahap ini mengkaji permasalahan dan menganalisis solusinya.

3. Design

Pada tahap ini yang dilukan pengembang perangkat lunak adalah mengimplementasikan model dan diagram yang telah dianalisis sebelumnya. Dalam merancang sistem dilengkapi dengan penggambaran visual menggunakan UML (Unified Modelling Language) 
4. Development

Pada tahap development, pengembang perangkat lunak melakukan implementasi terhadap design yang telah dilakukan dengan cara membangun atau mulai melakukan development terhadap kode-kode program serta user interface-nya.

5. Deployment

Tahap deployment adalah tahap pendistribusian produk yang dihasilkan kepada pengguna. Namun, tahapan yang dilakukan penelitian ini, hanya sampai pada tahapan development.

\subsection{Perancangan User}

Sistem perangkat lunak akan di gambarkan ke dalam dua diagram pada UML yaitu diagram usecase dan diagram activity. Secara singkat diagram usecase merupakan diagram utama UML yang menggambarkan hubungan antara aktor-aktor dengan proses-proses utama dalam sistem. Rancangan diagram usecase dapat dilihat pada Gambar 2.

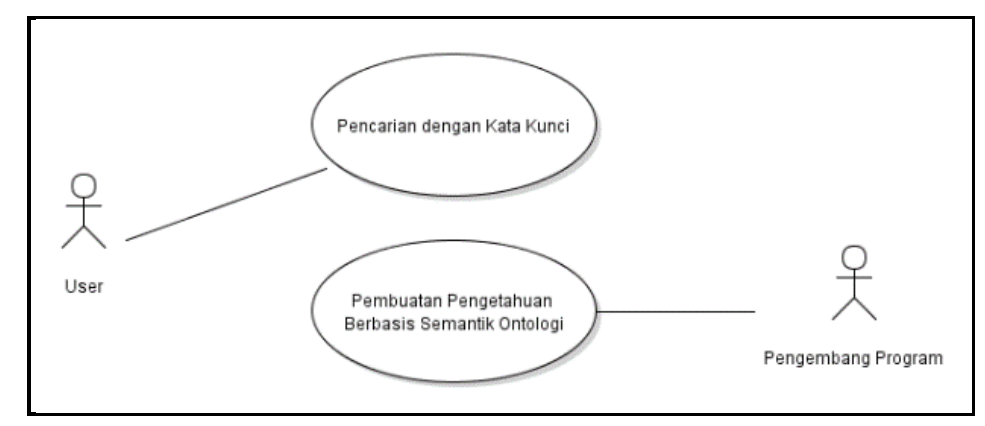

Gambar 2. Rancangan Diagram Usecase

Pada gambar 2 terdapat dua aktor yaitu user dan pengembang program, dimana aktivitas yang dilakukan user adalah dengan melakukan pencarian dengan kata kunci, sedangkan aktor lainnya yaitu pengembang program melakukan aktivitas dengan membuat pengetahuan berbasis semantik ontologi. Setelah merancang diagram usecase maka, dirancanglah diagram activity. Diagram activity atau yang dapat desebut diagram aktivitas menggambarkan berbagai alur aktivitas dalam sistem yang sedang dirancang, menggambarkan bagaimana masing-masing alur berawal, decision yang mungkin terjadi, serta bagaimana alur tersebut berakhir. Gambar 3 menggambarkan rancangan diagram activity pada user.

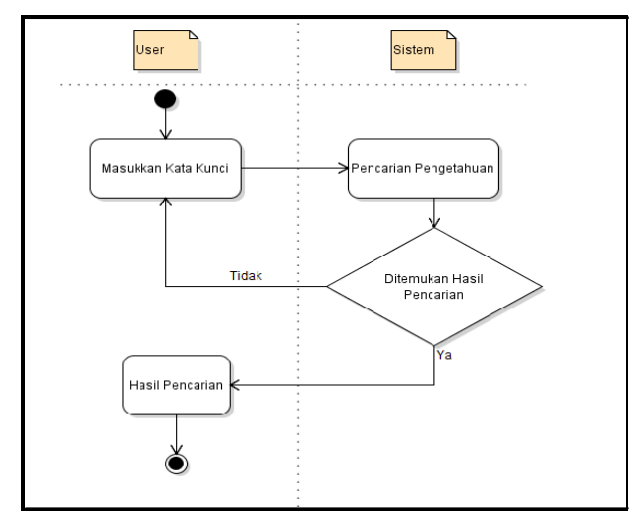

Gambar 3. Diagram Activity User

Gambar 3 menjelaskan rancangan diagram activity pada user dimana menggambarkan aktivitas user secara detail. Aktivitas yang dilakukan seorang user adalah melakukan pencarian dengan memasukkan kata kunci. Diagram activity pada pengembang program akan digambarkan pada Gambar 4 berikut ini. 


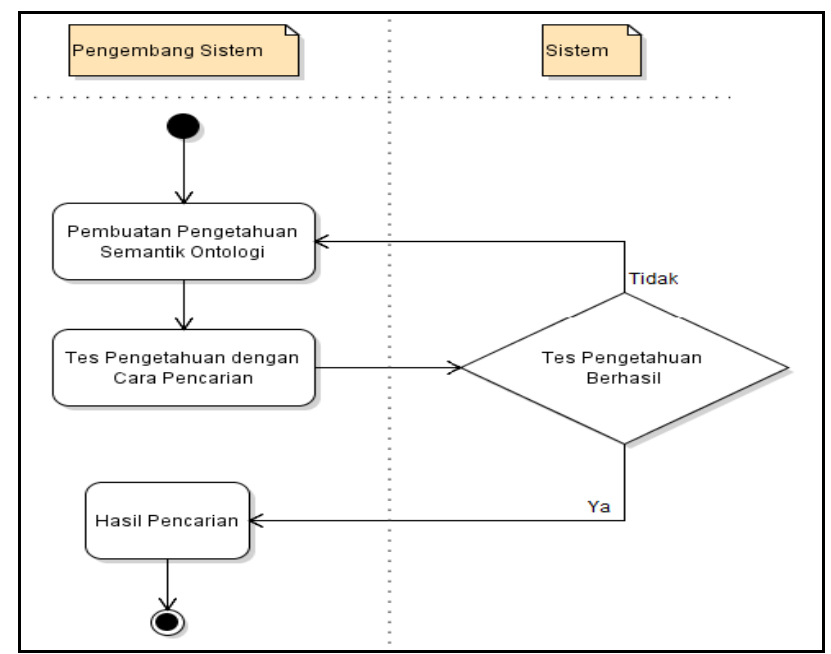

Gambar 4. Diagram Activity Pengembang

Aktivitas yang dilakukan oleh pengembang program adalah dengan membuat pengetahuan berbasis semantik ontologi, kemudian melakukan pengujian dengan cara melakukan pencarian, apabila hasil uji berhasil maka tugas atau aktivitas seorang pengembang program telah usai.

\section{HASIL DAN PEMBAHASAN}

\subsection{Rancangan Ontologi}

Sesuai dengan batasan masalah yang diangkat bahwasanya pengetahuan ontologi yang akan dirancang terbatas pada beberapa kasus. Sehingga, pada penelitian ini ontologi yang dirancang guna memberikan referensi baru terhadap teknologi pengolaan data kepolisian hanya merepresentasikan pengetahuan terkait kasus pencurian.

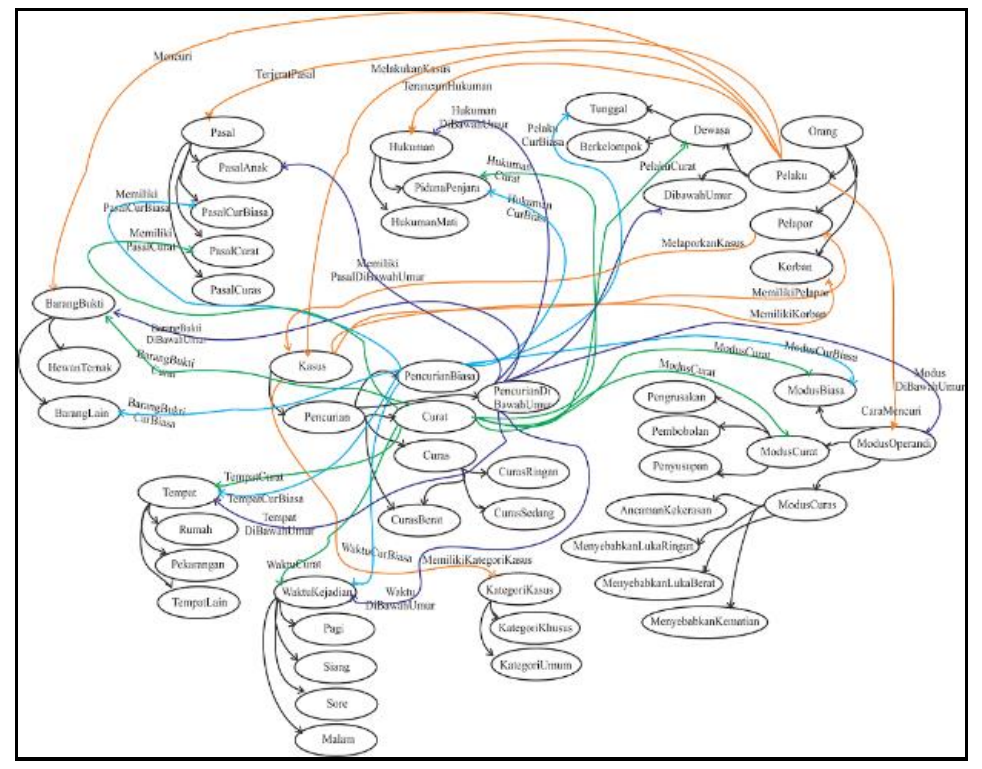

Gambar 5. Rancangan Ontologi 


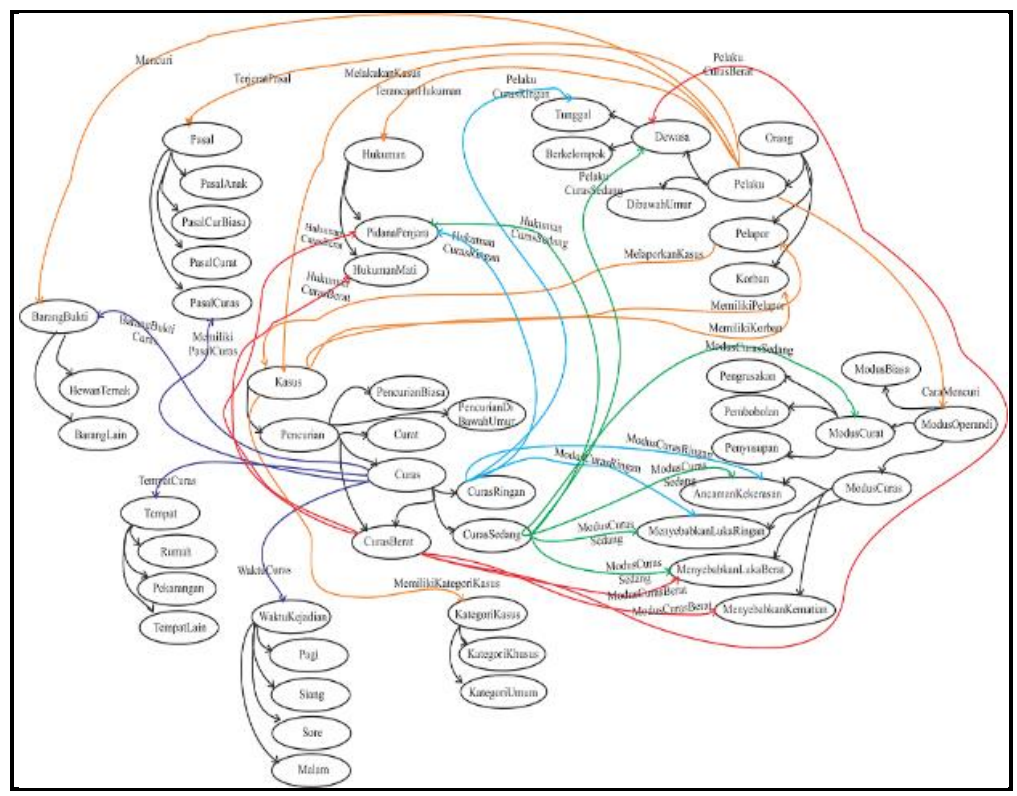

Gambar 6. Lanjutan Rancangan Ontologi

Pada Gambar 5 dan Gambar 6 menjelaskan bahwa pencurian tergolong menjadi beberapa kategori, diantaranya adalah pencurian biasa, pencurian dengan pemberatan maupun pecurian dengan kekerasan. Rancangan ontologi menggambarkan relasi relasi yang dibutuhkan pada setiap kategori kasus pencurian.

\subsection{Penentuan Class}

Class yang terdapat pada rancangan ontologi dapat dilihat pada gambar berikut ini :

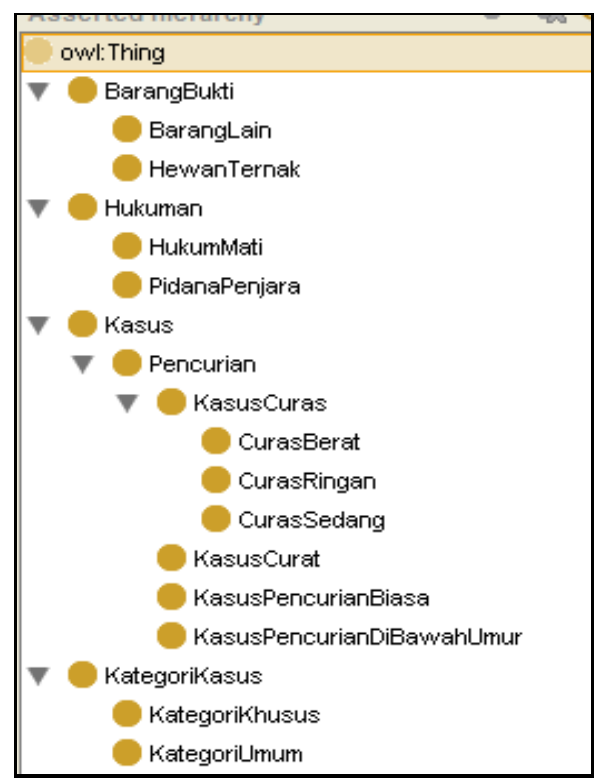

\section{Gambar 7. Daftar Class}




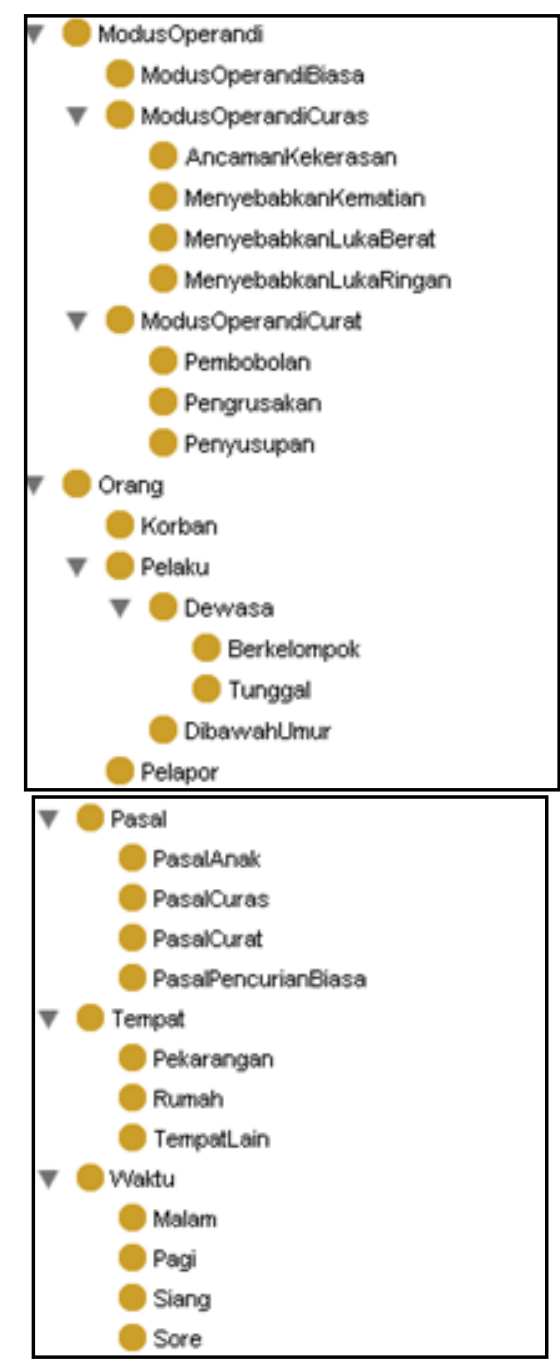

Gambar 8. Lanjutan Daftar Class

\subsection{Penentuan Object Property}

\begin{tabular}{|l}
\hline$\square$ BarangBuktiCuras \\
$\square$ BarangBuktiCurat \\
$\square$ BarangBuktiCurBiasa \\
$\square$ BarangBuktiDiBawahUmur \\
$\square$ Caramencuri \\
$\square$ HukumanCurasBerat \\
$\square$ HukumanCurasRingan \\
$\square$ HukumanCurasSedang \\
$\square$ HukumanCurat \\
$\square$ HukumanCurBiasa \\
$\square$ HukumanDiBawahUmur \\
$\square$ MelakukanKasus \\
$\square$ MelaporkanKasus \\
$\square$ Memilikikategorikasus \\
$\square$ Memilikikorban \\
$\square$ MemilkiPasalCuras \\
$\square$ MemilikiPasalCurat \\
$\square$ MemilikiPasalCurBiasa \\
$\square$ MemilikiPasalDiBawahumur \\
$\square$ MemilikiPelapor
\end{tabular}

Gambar 9. Daftar Object Property 


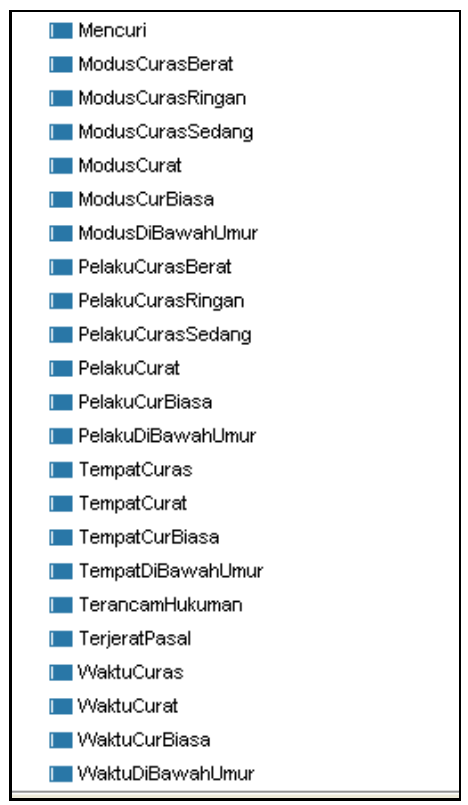

Gambar 10. Lanjutan Daftar Object Property

Tabel 1. Object Property

\begin{tabular}{|l|l|l|}
\hline \multicolumn{1}{|c|}{ Properti } & Kelas Domain & \multicolumn{1}{|c|}{ Kelas Range } \\
\hline Mencuri & Pelaku & BarangBukti \\
\hline TerjeratPasal & Pelaku & Pasal \\
\hline MelakukanKasus & Pelaku & Kasus \\
\hline TerancamHukuman & Pelaku & Hukuman \\
\hline CaraMencuri & Pelaku & ModusOperandi \\
\hline MemilikiKorban & Kasus & Korban \\
\hline MemilikiPelapor & Kasus & Pelapor \\
\hline MemilikiKategoriKasus & Kasus & KategoriKasus \\
\hline MemilikiPasalCurBiasa & KasusPencurianBiasa & Pasal \\
& & CurBiasa \\
\hline MemilikiPasalCurat & KasusCurat & PasalCurat \\
\hline MemilikiPasalCuras & KasusCuras & PasalCuras \\
\hline $\begin{array}{l}\text { MemilikiPasal } \\
\text { DiBawahUmur }\end{array}$ & KasusPencurianDiBawah & PasalAnak \\
\hline UmukumanCurBiasa & KasusPencurianBiasa & PidanaPenjara \\
\hline HukumanCurat & KasusCurat & PidanaPenjara \\
\hline HukumanDiBawahUmur & KasusPencurianDiBawah & Hukuman \\
& Umur & \\
\hline HukumanCurasRingan & KasusCuras Ringan & PidanaPenjara \\
\hline HukumanCurasSedang & KasusCurasSedang & PidanaPenjara \\
\hline HukumanCurasBerat & KasusCurasBerat & PidanaPenjara \\
\hline HukumanCurasBerat & KasusCurasBerat & HukumanMati \\
\hline PelakuCurBiasa & KasusPencurianBiasa & Tunggal \\
\hline PelakuCurat & KasusCurat & Dewasa \\
\hline PelakuDiBawahUmur & $\begin{array}{l}\text { KasusPencurianDiBawah } \\
\text { Umur }\end{array}$ & DiBawahUmur \\
\hline PelakuCurasRingan & KasusCurasRingan & Dewasa \\
\hline PelakuCurasSedang & KasusCurasSedang & Dewasa \\
\hline PelakuCurasBerat & KasusCurasBerat & Dewasa \\
\hline & & \\
\hline
\end{tabular}


Tabel 2. Lanjutan Object Property

\begin{tabular}{|c|c|c|}
\hline Properti & Kelas Domain & Kelas Range \\
\hline ModusCurBiasa & KasusPencurianBiasa & ModusOperandiBiasa \\
\hline \multirow[t]{2}{*}{ ModusCurat } & \multirow[t]{2}{*}{ KasusCurat } & ModusOperandiBiasa \\
\hline & & ModusOperandiCurat \\
\hline ModusDiBawahUmur & $\begin{array}{l}\text { KasusPencurianDiBawah } \\
\text { Umur }\end{array}$ & ModusOperandi \\
\hline \multirow{2}{*}{ ModusCurasRingan } & \multirow[t]{2}{*}{ KasusCurasRingan } & AncamanKekerasan \\
\hline & & MenyebabkanLukaRingan \\
\hline \multirow{4}{*}{ ModusCurasSedang } & \multirow{4}{*}{ KasusCurasSedang } & ModusCurat \\
\hline & & $\begin{array}{l}\text { Ancaman } \\
\text { Kekerasan }\end{array}$ \\
\hline & & $\begin{array}{l}\text { Menyebabkan } \\
\text { LukaRingan }\end{array}$ \\
\hline & & $\begin{array}{l}\text { Menyebabkan } \\
\text { LukaBerat }\end{array}$ \\
\hline \multirow[t]{2}{*}{ ModusCurasBerat } & \multirow[t]{2}{*}{ KasusCurasBerat } & MenyebabkanLukaRingan \\
\hline & & MenyebabkanLukaBerat \\
\hline WaktuCurBiasa & KasusPencurianBiasa & WaktuKejadian \\
\hline WaktuCurat & KasusCurat & WaktuKejadian \\
\hline WaktuCuras & KasusCuras & WaktuKejadian \\
\hline WaktuDiBawahUmur & KasusDiBawahUmur & WaktuKejadian \\
\hline TempatCurBiasa & KasusPencurianBiasa & Tempat \\
\hline TempatCurat & KasusCurat & Tempat \\
\hline TempatCuras & KasusCuras & Tempat \\
\hline TempatDiBawahUmur & KasusDiBawahUmur & Tempat \\
\hline BarangBuktiCurBiasa & KasusPencurianBiasa & BarangLain \\
\hline BarangBuktiCurat & KasusCurat & BarangBukti \\
\hline BarangBuktiCuras & KasusCuras & BarangBukti \\
\hline BarangBuktiDiBawahUmur & KasusDiBawahUmur & BarangBukti \\
\hline
\end{tabular}

\subsection{Penentuan Data Type Property}

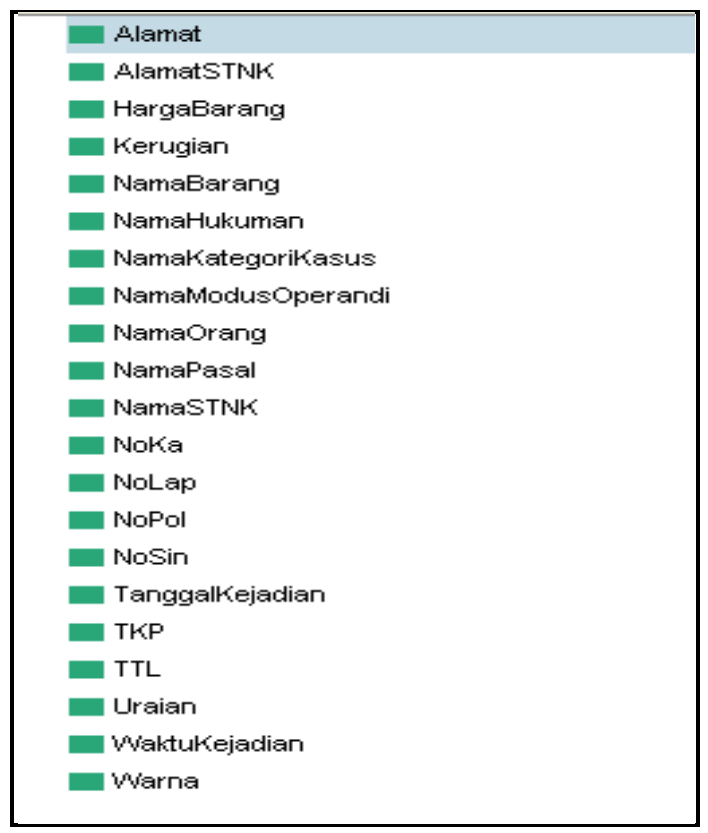

Gambar 11. Daftar Data Type Property 
Tabel 3. Data Type Property

\begin{tabular}{|l|l|l|l|}
\hline Kelas & Data Properties & Domain & Tipe \\
\hline Orang & Nama Orang & Orang & String \\
\hline Orang & Alamat & Orang & String \\
\hline Orang & TTL & Orang & String \\
\hline Pasal & NamaPasal & Pasal & String \\
\hline BarangBukti & NamaBarang & BarangBukti & String \\
\hline BarangBukti & Warna & BarangBukti & String \\
\hline BarangBukti & HargaBarang & BarangBukti & Integer \\
\hline BarangBukti & NamaSTNK & BarangBukti & String \\
\hline BarangBukti & AlamatSTNK & BarangBukti & String \\
\hline BarangBukti & NoPol & BarangBukti & String \\
\hline BarangBukti & NoKa & BarangBukti & String \\
\hline BarangBukti & NoSin & BarangBukti & String \\
\hline Kasus & NoLap & Kasus & String \\
\hline Kasus & Uraian & Kasus & String \\
\hline Kasus & TglKejadian & Kasus & String \\
\hline Kasus & Kerugian & Kasus & Int \\
\hline Tempat & TKP & Tempat & String \\
\hline Waktu & WaktuKejadian & Waktu & String \\
\hline ModusOperandi & NamaModusOperandi & KategoriModus & String \\
\hline KategoriKasus & NamaKategoriKasus & KategoriKasus & String \\
\hline Hukuman & NamaHukuman & Hukuman & String \\
\hline
\end{tabular}

\subsection{Penentuan Instance/Individual}

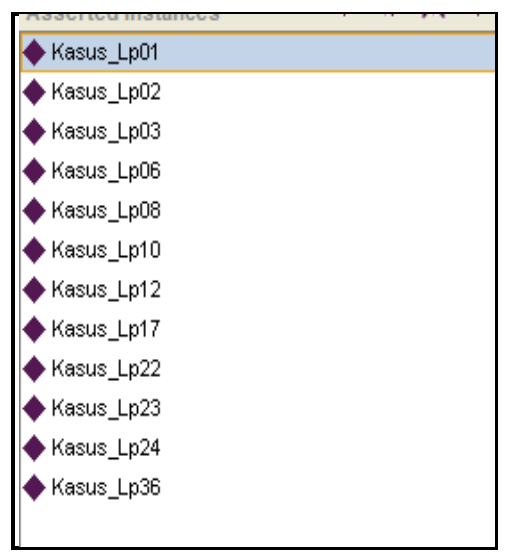

Gambar 12. Beberapa Contoh Instance 


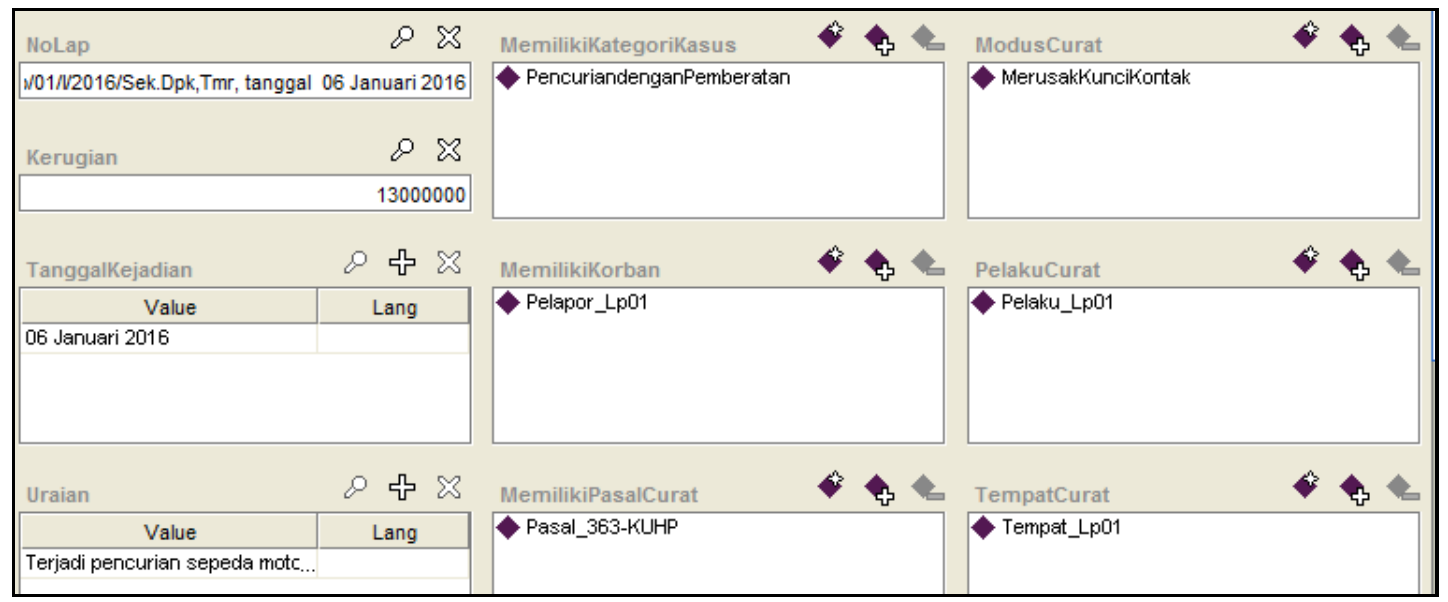

\section{Gambar 13. Pengisian Atribut}

\subsection{Pengujian Query SPARQL}

PREFIX ontol: <http://www.owl-ontologies.com/OntologyKasus.owl\#> PREFIX owl: <http://www.w3.org/2002/07/owl\#>

SELECT DISTINCT ?kasus ?kasus2 ?NoLap ?NamaKasus WHERE \{

\{?kasus ontol:NoLap ?NoLap\}.

\{?kasus ontol:TanggalKejadian ?TGL\}.

$\{$ ?kasus ontol:Uraian ?URAIAN\}.

\{?kasus owl:sameAs ?kasus2\}.

\{?kasus2 ontol:NamaKategoriKasus ?NamaKasus\} union \{?kasus2 ontol:NamaModusOperandi ?NamaKasus\}.

FILTER (REGEX(str(?NamaKasus),"Pencurian pada pagi hari","i") )

ORDER BY ?NoLap

Modul Program 1. Pengujian SPARQL

\begin{tabular}{|l|c|}
\hline \multicolumn{1}{|c|}{ kasus } & \multicolumn{1}{c|}{ kasus2 } \\
\hline Kasus_Lp03 & PencuriarPadaPaghtari \\
Kasus_Lp12 & PencurianPadaPaghtari \\
Kasus_Lp36 & PencurianPadaPagiHari \\
\hline
\end{tabular}

Gambar 14. Hasil Query Modul Program 1 
PREFIX ontol: <http://www.owl-ontologies.com/OntologyKasus.owl\#> PREFIX owl: <http://www.w3.org/2002/07/owl\#>

SELECT DISTINCT ?kasus ?kasus2 ?NoLap WHERE \{

\{?kasus ontol:NoLap ?NoLap\}.

\{?kasus ontol:TanggalKejadian ?TGL\}.

\{?kasus ontol:Uraian ?URAIAN\}.

\{?kasus owl:sameAs ?kasus2\}.

\{?kasus2 ontol:NamaKategoriKasus ?NamaKasus\} union \{?kasus2 ontol:NamaModusOperandi ?NamaKasus\}.

FILTER (REGEX(str(?NoLap),"Lp/19","i") )

\}

ORDER BY ?NoLap

Modul Program 2. Pengujian SPARQL 2

\begin{tabular}{|c|c|c|}
\hline \multicolumn{3}{|l|}{ Results } \\
\hline kasus & kasus2 & \\
\hline Kasus_Lp18 & - PencurianPadaatiritidan & 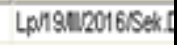 \\
\hline Kasus_tp19 & - PencurianPadialalanthari & Lphan:2016iSek. \\
\hline
\end{tabular}

Gambar 15. Hasil Query Modul Program 2.

\subsection{Pengujian Program}

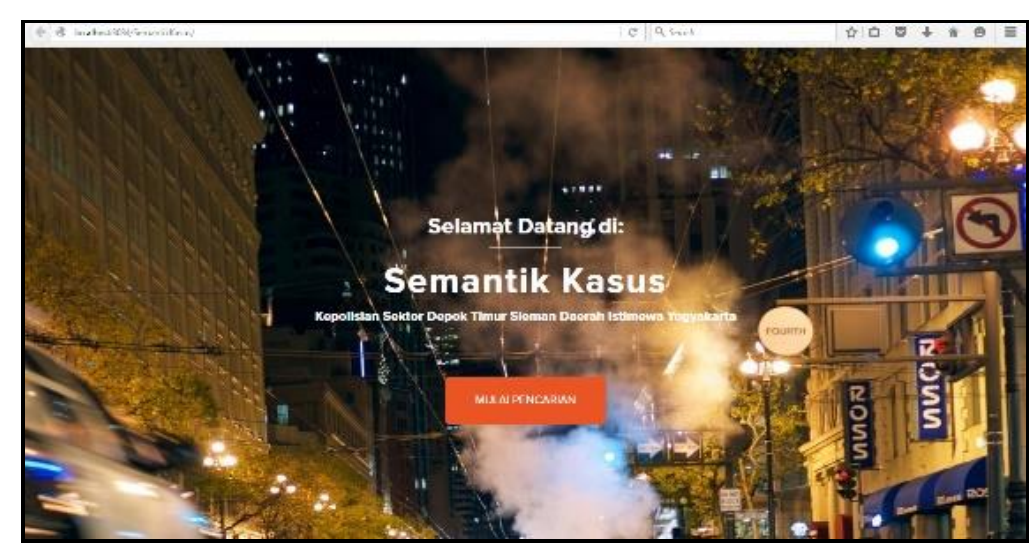

Gambar 16. Halaman Awal Pengujian 


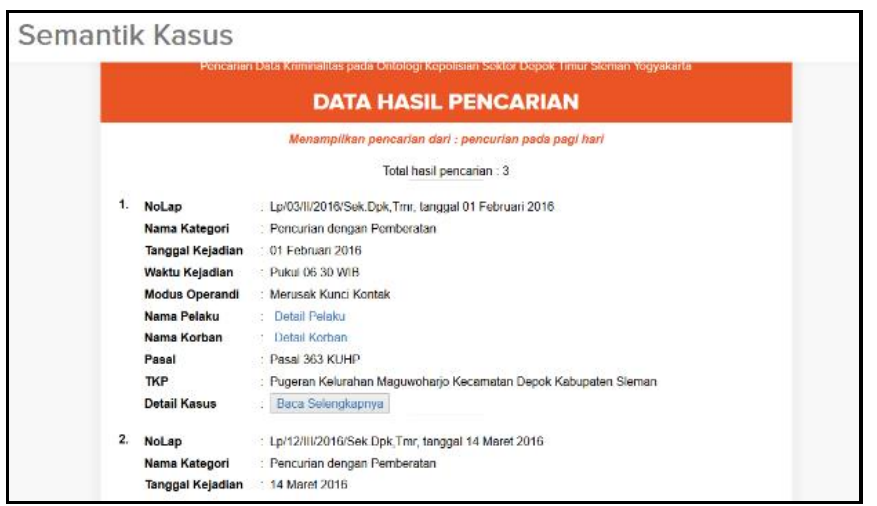

Gambar 17. Pencarian Kasus dengan Kata Kunci “Pagi Hari”

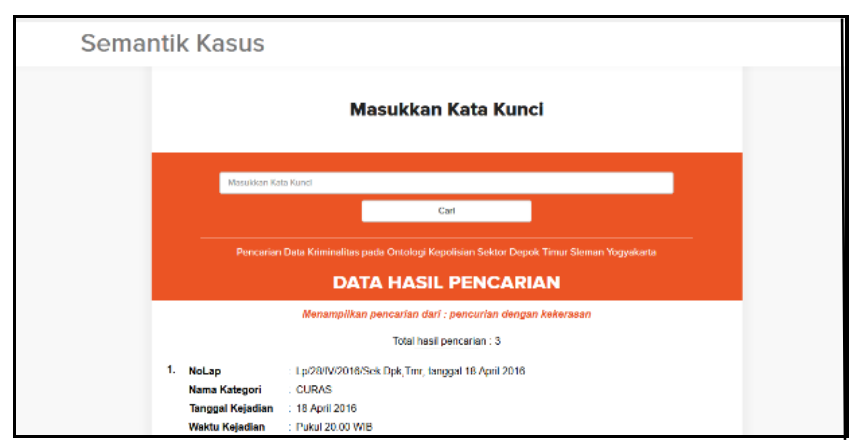

Gambar 18. Pencarian Kasus dengan Kata Kunci "Curas”

\subsection{Hasil Pengujian}

Pengujian dengan menggunakan metode recall dan precision menghasilkan hasil uji sebagai berikut ini :

Tabel 4. Pengujaian Precision dan Recall

\begin{tabular}{|l|l|l|l|l|l|l|}
\hline No & Kalimat Pencarian & $\begin{array}{l}\text { Jumlah } \\
\text { Dokumen } \\
\text { Relevan } \\
\text { Pada } \\
\text { Ontologi }\end{array}$ & $\begin{array}{l}\text { Jumlah } \\
\text { Dokumen } \\
\text { yang } \\
\text { Diterima }\end{array}$ & $\begin{array}{l}\text { Jumlah } \\
\text { Dokumen } \\
\text { Relevan } \\
\text { yang Diterima }\end{array}$ & Precision & Recall \\
\hline 1. & Pencurian dengan pemberatan & 12 & 12 & 12 & $100 \%$ & $100 \%$ \\
\hline 2. & Pencurian biasa & 3 & 3 & 3 & $100 \%$ & $100 \%$ \\
\hline 3. & Pencurian dengan kekerasan & 4 & 4 & 4 & $100 \%$ & $100 \%$ \\
\hline 4. & Pencurian pada pagi hari & 3 & 3 & 3 & $100 \%$ & $100 \%$ \\
\hline 5. & Pencurian pada siang hari & 5 & 5 & 4 & $80 \%$ & $80 \%$ \\
\hline 6. & Pencurian pada sore hari & 4 & 4 & 4 & $100 \%$ & $100 \%$ \\
\hline 7. & Pencurian pada malam hari & 7 & 7 & 7 & $100 \%$ & $100 \%$ \\
\hline 8. & Pencurian pada awal bulan & 8 & 8 & 8 & $100 \%$ & $100 \%$ \\
\hline 9. & Pencurian pada tengah bulan & 6 & 6 & 6 & $100 \%$ & $100 \%$ \\
\hline 10 & Pencurian pada akhir bulan & 5 & 5 & 5 & $100 \%$ & $100 \%$ \\
\hline 11. & Pencurian Sepeda & 1 & 1 & 1 & $100 \%$ & $100 \%$ \\
\hline 12. & Pencurian Sepeda Motor & 6 & 6 & 6 & $100 \%$ & $100 \%$ \\
\hline & Total & 64 & 64 & 63 & $98 \%$ & $98 \%$ \\
\hline
\end{tabular}

\section{KESIMPULAN}

Berdasarkan hasil analisis, perancangan dan implementasi yang dilakukan pada bab-bab sebelumnya, maka kesimpulan yang dapat diambil adalah sebagai berikut: 
1. Data kriminalitas kepolisian dapat direpresentasikan menjadi sebuah pengetahuan berbasis semantik ontologi dengan memanfaatkan aplikasi protégé 3.5, yang kemudian pengetahuan tersebut ditampilkan dalam bentuk aplikasi berbasis pencarian.

2. Dengan melakukan representasi pengetahuan berbasis semantik ontologi pada data kriminalitas kepolisian, kurang lebih dapat memenuhi tujuan dalam penelitian ini yaitu meningkatkan efektifitas pencarian data kriminalitas, mengingat hasil uji pada recall dan precision masing-masing menunjukkan nilai $98 \%$. Pada dasarnya nilai keefektifan suatu pencarian tergantung dari bagaimana cara merepresentasikan data ke dalam bentuk representasi pengetahuan berbasis semantik ontologi.

\section{SARAN}

Mengingat adanya kekurangan dalam penelitian ini sehingga diperlukan beberapa saran. Saran yang dapat diberikan sebagai hasil penelitian dalam tugas akhir ini adalah sebagai berikut :

1. Mengingat pengetahuan penulis mengenai ilmu hukum sangat terbatas serta adanya batasan pada representasi pengetahuan kasus kriminalitas, sehingga perlu dilakukan pengembangan dan perluasan konsep-konsep pengetahuan terkait data kriminalitas lainnya agar dapat mencakup semua pengetahuan terkait ontologi pada domain data kriminalitas.

2. Kelemahan aplikasi pada penelitian ini adalah belum dapat melakukan penembahan data pengetahuan secara otomatis sehingga perlu adanya pengembangan untuk menciptakan aplikasi yang dapat melakukan penambahan pengetahuan terutama dalam menambahkan individual/instance secara otomatis sehingga memudahkan dalam mengelola basis pengetahuan yang ada.

3. Perlu dikembangkan bentuk aplikasi pencarian yang dapat melakukan pencarian bukan hanya dengan memasukkan kata kunci melainkan dengan memasukkan sebuah kalimat pencarian yang didukung dengan penanganan kesalahan ketik secara otomatis.

\section{DAFTAR PUSTAKA}

Antoniou, G., \& Van Harmelen, F. (2004). Web ontology language: Owl. In Handbook on ontologies (pp. 67-92). Springer. Retrieved from http://link.springer.com/chapter/10.1007/978-3-540-24750-0_4

Bechhofer, S. (2009). OWL: Web ontology language. In Encyclopedia of Database Systems (pp. 2008-2009). Springer. Retrieved from http://link.springer.com/10.1007/978-0-38739940-9_1073

Berners-Lee, T., Hendler, J., Lassila, O., \& others. (2001). The semantic web. Scientific American, 284(5), 28-37.

Brickley, D., Guha, R. V., \& McBride, B. (2014). RDF Schema 1.1. W3C Recommendation, 25, 2004-2014.

Davies, J., Studer, R., \& Warren, P. (2006). Semantic Web technologies: trends and research in ontology-based systems. John Wiley \& Sons. Retrieved from https://www.google.com/books?hl=id\&lr=\&id=ePCrymWkcl0C\&oi=fnd\&pg=PR1\&dq=+ Davies,+J.,+Studer,+R.,+dan+Warren,+P.,+2006.++Semantic+web+Teknologies+Tre nds+and+Research+in+Ontology-

based+Systems.+John+Wiley+\%26+Sons.+Chichester.+\&ots=wvv7mx841W\&sig=H_J O0TrjPay6zYcZDu7gdWcPvP8

Gantini, T., \& Mendrofa, P. I. P. (2012). Pembuatan Perangkat Lunak Aplikasi Pengelolaan Data Kasus Perkara di Kepolisioan Resor Kota Bandung Barat. Jurnal Informatika, 6(1), p83.

Gruber, T. (1993). What is an Ontology. WWW Site Http://www-Ksl. Stanford. Edu/kst/whatis-anOntology. Html (Accessed on 07-09-2004). Retrieved from https://pdfs.semanticscholar.org/08ca/030f827f38bf1ac17b5886adefd3cc2d3264.pdf

Herlina, J. (2011). Strategi Pengelolaan Pengetahuan (knowledge management) Pemilihan Anggota Legislatif di Daerah Istimewa Yogyakarta. Telematika, (14).

Herman, I. (2008). SPARQL is a Recommendation. W3C Semantic Web Activity News. 
Jayadianti, H., Nugroho, L. E., Sanntosa, P. I., Widayat, W., \& Pinto, C. S. (2015). Ontology Sebagai Solusi Pencarian Makna Ambigu dalam Sistem yang Heterogen. Telematika, 10(1). Retrieved from http://jurnal.upnyk.ac.id/index.php/telematika/article/view/386

Koivunen, M.-R., \& Miller, E. (2001). W3c semantic web activity. Semantic Web Kick-Off in Finland, 27-44.

Lassila, O., \& Swick, R. R. (1999). Resource description framework (RDF) model and syntax specification. Retrieved from http://www.citeulike.org/group/884/article/634743

McGuinness, D. L., Van Harmelen, F., \& others. (2004). OWL web ontology language overview. W3C Recommendation, 10(10), 2004.

Syafii, A. (2015). Tindak Pidana Pencurian Menurut KUHP.

Winantu, A., \& others. (2016). Pengembangan Purwarupa Semantic Search Menggunakan Semantic Web Rule Language Untuk Pencarian Informasi Produk. Jurnal Fahma, 14(2). Retrieved from http://portal.ejurnal.net/index.php/fahma/article/view/1333

Yunita, Y., \& Mustafa, K. (2015). Pemanfaatan Semantik Web Rule Language (SWRL) dalam Pengembangan Prototype Sistem Perencanaan Paket Perjalanan Wisata di Sumatera Selatan. In Seminar Nasional Informatika (SEMNASIF) (Vol. 1). Retrieved from http://jurnal.upnyk.ac.id/index.php/semnasif/article/view/1068 